\title{
Going-Concern Debt of Financial Intermediaries
}

\author{
Yueran Ma and Jose Scheinkman ${ }^{1}$
}

We analyze the importance of asset-based debt and going-concern based debt among US financial intermediaries. Asset-based debt is based on the resale value of specific assets, which includes repurchase agreements as well as other collateralized financing secured by securities or loans. Going-concern based debt is based on the firm's going-concern enterprise value (such as those generated by commercial lending, derivatives, services, networks, etc.), and generally takes the form of unsecured long-term bonds in the case of financial institutions.

We document five main facts among US public financial intermediaries.

First, in the aggregate, the resale value of directly pledgeable assets accounts for about $60 \%$ of financial intermediaries' enterprise value. While this ratio is much higher than that of non-financial firms (around 20\%), going-concern value still accounts for a sizable fraction of aggregate enterprise value. This share decreases substantially with size, that is, smaller financial institutions have a higher share of asset value coming directly from the resale value of collateralizable assets. This size dependence is especially strong among financial firms, and not as significant among non-financial firms.

Second, in the aggregate, the value of going-concern debt is almost as large as that of asset-based debt. Going-concern debt as a share of total assets is about 25\% among investment banks and about $10 \%$ among commercial banks. The high share is also particularly pronounced among large institutions.

Third, there is a significant negative correlation between the share of total asset value coming from the resale value of directly pledgeable assets, and the share of assets financed with going-concern debt. In other words, firms with a smaller portion of asset value coming from the resale value of collateralizable assets have more going-concern debt. This pattern is consistent with patterns in non-financial firms.

Fourth, the going-concern debt of financial intermediaries has much lighter covenants than that of non-financial firms. While going-concern cash flow-based debt of nonfinancial firms tends to have strong control rights to guard against potential moral hazard problems, going-concern debt of financial institutions has weak rights. Before the crisis, creditors of financial intermediaries' going-concern debt may have relied on implicit government guarantee as a substitute mechanism. Recent financial regulations, such as total loss-absorbing capacity (TLAC) requirements, explicitly limit the rights of financial

\footnotetext{
${ }^{1}$ University of Chicago and Columbia University. Emails: yueran.ma@ chicagobooth.edu, js3317@columbia.edu.
} 
intermediaries' going-concern debt and also limit government bailouts. With neither creditor control rights nor bailout protection, the cost of going-concern debt could be high.

Taken together, our findings suggest that financial institutions, especially large institutions, are not just about holding collateralizable assets. Rather, a significant portion of value lies in their going concern. Correspondingly, going-concern based debt is still important for financial institutions. However, enforcing going-concern based debt may faced unique challenges in the context of financial intermediaries, given the difficulty in the orderly restructuring of institutions that engage in liquidity provision. 